\title{
Barriers, enablers and strategies for the treatment and control of hypertension in Nepal: a mixed-methods systematic review
}

Raja Ram Dhungana ( $\square$ raja.dhungana@gmail.com )

Government of Nepal Department of Livestock Services https://orcid.org/0000-0002-9610-6306

Zeljko Pedisic

Victoria University

Achyut Raj Pandey

ABT Associates Inc

Nipun Shrestha

Victoria University

Maximilian de Courten

Victoria University

Research

Keywords: Barriers; Facilitators; Strategies; Hypertension; Treatment; Control; Nepal

Posted Date: July 25th, 2020

DOI: https://doi.org/10.21203/rs.2.20936/v3

License: (c) (i) This work is licensed under a Creative Commons Attribution 4.0 International License. Read Full License

Version of Record: A version of this preprint was published at Frontiers in Cardiovascular Medicine on October 11th, 2021. See the published version at https://doi.org/10.3389/fcvm.2021.716080. 


\section{Abstract}

Background: The challenge of achieving effective treatment and control of blood pressure is linked to various barriers to hypertension care at different layers of health system (HS). Evidence is emerging globally on the effectiveness of multi-pronged hypertension control strategies. However, no systematic review of strategies of and factors associated with hypertension treatment and control in Nepal is available. Understanding country-specific factors influencing hypertension care is critical to address the gaps in the management of hypertension. This study aimed to systematically review published literature and synthesise the findings on barriers, enablers and strategies for hypertension treatment and control in Nepal.

Methods: Six databases namely Embase, PubMed, Web of Science, CINAHL, ProQuest and WorldCat, Nepali journals and Nepal government websites were systematically searched for qualitative, quantitative and mixed-methods studies investigating the factors or strategies in relation to hypertension treatment and control in Nepal. The methodological quality of selected articles was assessed using Mixed Methods Appraisal Tool. Themes on barriers and enablers were generated and framed under "health system", "provider" and "patient" domains, according to the framework synthesis approach. Findings on hypertension strategies were narratively synthesised.

Results: We identified 14 published studies; one with mixed, three with qualitative and 10 with quantitative methods. Eight were related to barriers and enablers and six of hypertension strategies. The identified barriers associated with the HS were: lack of affordable services and lack of resources. The barriers at the provider's level were: communication gaps and long waiting hours for appointments. Poor help-seeking behaviour, non-adherence to medication, perceived side-effects of drugs, financial hardship and lack of family support were barriers identified at patient level. The following enablers were identified: positive illness perception, free essential healthcare services and family support. Strategies implemented across the HS, provider and patient were: establishing digital health records at health centres, health worker's capacity development, health education and yoga practice.

Conclusion: There is a range of barriers for hypertension treatment and control in Nepal pertaining to the HS, providers, and patients. Comprehensive interventions are needed at all three levels to further improve management and control of hypertension in Nepal.

Registration: The protocol is registered in PROSPERO (registration number: CRD42020145823)

\section{Background}

A political declaration on the prevention and control of non-communicable diseases (NCDs), adopted by the General Assembly of the United Nations in 2011, emphasises the importance of developing national capacities to deal with NCDs, particularly in low-and middle-income countries (LMICs) [1]. Though more and more focus of the HS is placed on tackling NCDs, the rate of hypertension treatment and control in LMICs is low [2]. Compared to high-income countries, LMICs reported substantially lower proportions of hypertension treatment (55.6\% vs. $29.0 \%$ ) and control (28.4\% vs. $7.7 \%$ ) in 2010 [3]. In three South Asian countries, namely, Bangladesh, India, and Pakistan, $31.9 \%$ of the hypertensive population was on anti-hypertensive medication and only $12.9 \%$ had controlled blood pressure [4].

Nepal, a South Asian low-income country landlocked between China and India hosts a population of 28 million, with 125 caste/ethnic groups living mostly in rural areas [38, 39]. Under the Ministry of Health and Population, the public HS in Nepal delivers health services to the community through the tertiary, district and primary care centres and health posts. Alongside public health services, private for-profit sectors and non-governmental organisations provide health services in Nepal [40].

With the growing burden of hypertension, untreated and uncontrolled hypertension is prevalent in Nepal [5-9]. The majority of hypertensive individuals were not aware of their condition (awareness $=40.0 \%$ ); a half of those that were aware were not treated (treatment $=20.2 \%$ ), and a half of those on treatment, the blood pressure was not controlled (control $=10.5 \%)$ in 2016 [10].

Gaps in hypertension treatment and control can be due to various factors associated with the HS, health care providers, and individual patients. Systematic reviews and other studies from outside of Nepal suggest that lack of access, poor service delivery, unaffordability of health services and limited resources are common HS-related barriers [11-16]. Similarly, studies also found that the factors pertaining to patients and providers, such as lack of awareness and treatment, non-adherence to medicine, adverse drug effect, therapeutic inertia and communication gaps, were contributing to uncontrolled hypertension [13, 16-26].

The quantity and the scope of primary research on barriers, enablers and strategies for hypertension control are growing in Nepal. While new evidence from primary studies is evolving, a systematic review is needed for a comprehensive identification, understanding and synthesis of the factors affecting hypertension treatment and control in the Nepali context. Therefore, this review aimed to systematically synthesise evidence on barriers, enablers, and strategies for hypertension treatment and control in Nepal. By providing a comprehensive understanding of HS- and individual-level barriers and enablers and strategies of hypertension treatment and control, this review aims to inform the policymakers and related stakeholders about the gaps in hypertension care and contribute to the development of the contextual and problem-specific strategies to increase hypertension control in Nepal.

\section{Theoretical framework}

A framework was used to organise patient, health care provider and HS (excluding patients and providers) barriers, enablers, and strategies for improving blood pressure control. The framework was derived from the theories used in previous studies on barriers [14, 16, 27], and adapted to also fit the enablers and strategies (Fig 1). 
By "barriers", we considered factors that prevent adequate blood pressure control [27]. These have previously been linked with hypertensive patients, providers, and HS [27]. Patient-reported barriers include, for example, knowledge, perception, beliefs, practices, self-efficacy, motivation, family support, affordability, and

socio-cultural factors such as social dining and drinking $[16,28]$. These factors may affect health-seeking behaviours, treatment adherence, and follow-up care among patients, ultimately affecting blood pressure control [27]. The commonly cited barriers by the providers comprise a lack of skills, non-compliance with guidelines, lack of motivation and therapeutic inertia [16, 26, 27]. An interaction of patient and provider factors can sometimes lead to a communication gap and a poor relationship, affecting treatment adherence and follow-up care [29].

Furthermore, enablers are the personal or contextual factors that facilitate actions or a required behaviour for hypertension treatment and control. They include, for example, perceived severity of illness and family support [30].

Strategies to improve blood pressure control include interventions, programs, or policies targeted at the providers, patients, or other components of the HS. Some of the proposed evidence-based strategies are: task shifting [31]; team-based care [32]; HS financing, including insurance coverage and co-payments of medical care [14]; HS arrangement, including improved service delivery [33]; using combination therapy [34] or polypill [35]; home-based blood pressure monitoring [36]; and educational interventions for patients and physicians [37].

\section{Methods}

We systematically searched the literature, selected eligible studies, assessed methodological quality, extracted relevant data and synthesised findings in accordance with the PRISMA guidelines [41]. The protocol has been registered in PROSPERO (registration number: CRD42020145823).

\section{Eligibility criteria}

We used the PICOS (P-Population; I- Intervention/Exposure; C-Control/Comparator; O-Outcome; S- Study design) model to frame our research questions and applied the same model to define the eligibility criteria for study selection.

\section{Population}

We included studies that provided information on any factors limiting or facilitating the performance of hypertension treatment and control in Nepal. These factors were associated with hypertensive patients, health care providers (physicians, nurses, healthcare workers, and others), or HS. We did not restrict studies according to participants' age, gender, ethnicity, or comorbidity.

\section{Exposure/Intervention}

We defined the exposure as any factor that reportedly impedes or facilitates hypertension treatment and control in Nepal [14, 27], excluding the non-modifiable personal attributes such as age, gender and ethnicity of patients and providers. Strategies were any interventions, program or policies targeted to the providers or patients or other components of HS and delivered at the community or health facility level for improving hypertension treatment and control.

\section{Comparator/ control}

We included studies with or without comparators or control groups. Some of the comparators or controls were untreated, uncontrolled hypertensive individuals, general population, or patients who receive usual care.

\section{Outcomes}

The outcomes of interest were hypertension treatment, hypertension control and treatment adherence. By "hypertension treatment" we considered the use of at least one antihypertensive medication by hypertensive patients [14]. We defined "hypertension control" as maintaining systolic blood pressure of < $140 \mathrm{mmHg}$ and diastolic blood pressure of $<90 \mathrm{mmHg}$ in individuals under antihypertensive medication [14]. "Medication adherence" was defined as consistently taking antihypertensive medication as prescribed by the health care provider [14].

\section{Types of study}

We included observational (qualitative, quantitative and mixed-methods) and experimental studies that assessed and quantified barriers, enablers and strategies for hypertension treatment and control in Nepal. Qualitative studies that provided information on views and experiences of patients, providers and other related stakeholders regarding barriers and enablers of hypertension treatment and control were also included in the review. Studies were included regardless of language of publication or sample size. Reviews, case reports, case series and conference abstracts were not deemed eligible for inclusion.

\section{Search strategy}

The primary literature search was conducted in PubMed, Embase, Web of Science, CINAHL through EBSCOHost, ProQuest and WorldCat databases. We used a comprehensive search strategy to identify hypertension-related literature published between 2000 and 2019 in Nepal. Barriers, enablers and strategies for 
hypertension treatment and control are likely to change over time. Therefore, to provide the most relevant data for informing changes in HS, this review focused on the current situation, and we only searched for the recent literature (i.e. published in the last 20 years). We combined the search terms "hypertension" and "blood pressure" with the search term "Nepal". The full search syntax is provided in Additional file 1.

The secondary search was done through Nepal Journals Online, Journal of Nepal Health Research Council, Journal of Kathmandu Medical College, Nepal Medical College Journal, Journal of Nepal Medical Association and Chitwan Medical College Journal to identify any relevant citations we may have missed in the primary search. We also accessed websites of the Nepali Government, professional and regulatory organisation, and national and international agencies. Finally, we conducted forward citation searching for included studies using Google Scholar database and screened the reference lists of the included studies, as part of a backward citation search.

\section{Data management}

We used EndNote X8 (Clarivate Analytics, Philadelphia, PA, USA) and Rayyan QCRI [42] to manage the records and other data throughout the review. At first, we exported the citations to EndNote X8 to identify and remove the duplicates. The citations were then imported to Rayyan QCRI, to carry out screening and data extraction.

\section{Selection process}

Initially, two authors (RRD and ARP) independently screened the titles and abstracts of the articles and labelled them as 'included', 'maybe' and 'excluded'. Fulltexts of all records except the ones that were labelled 'excluded' by both reviewers were reviewed. The screening process was blinded, and all disagreements in study selection were settled by consensus between the two authors. A PRISMA flow chart illustrating the study selection process is presented in Figure 2 .

\section{Data extraction}

Using a pre-designed form, two authors (RRD and ARP) independently extracted the following data from the included publications: study design; study types; study participants; study setting; statistical method; year of publication; information to assess the risk of bias; types and/or prevalence of barriers, enablers, and strategies; and the effects on hypertension awareness, treatment, and control. For strategies, we additionally extracted data related to the comparator group.

\section{Quality assessment}

We used the Mixed Methods Appraisal Tool (MMAT) to assess the methodological quality of the selected studies. MMAT includes a five-item checklist for different types of study design, with 'Yes' 'No' and 'Can't tell' response options (Additional file 2). For each 'Yes' response, the given study was assigned a star $\left.{ }^{*}\right)$. A study could, therefore, get an overall score between zero and five stars. For the purpose of this review, we used the following scoring system for overall methodological quality: 0-1 star = 'low'; 2-3 stars = 'fair'; 4-5 stars = 'good'. Two authors (RRD and ARP) independently checked the quality of the studies. To resolve discrepancies between assessment scores provided by the two authors, a third author (NS) also assessed the quality of the studies using the same tools. All conflicts were resolved by consensus. We did not exclude studies from the review based on the outcome of quality assessment.

\section{Data synthesis}

Extracted qualitative data were coded and merged into themes. Themes relating to the institution, resource, finance and services were categorised as HS factors. Attitudes, perceptions, practices, behaviours and beliefs of patients and providers were listed under their respective domains.

We calculated the odds ratios and their $95 \%$ confidence interval $(\mathrm{Cl})$ using the proportions of exposure and outcomes, where available. Due to the limited information on the exposures and outcome and large methodological heterogeneity between the selected studies, we summarised the quantitative study findings narratively.

\section{Results}

\section{Study selection}

The systematic search of six electronic databases resulted in a total of 2175 records. We removed 767 duplicates in Endnote and exported the remaining 1408 records to Rayyan QCRI for the title and abstract screening. We excluded 1302 ineligible titles and abstracts and retrieved the full-texts of the remaining 106. Out of 106 full-text articles that we assessed, 94 had either ineligible outcomes, were conducted among non-hypertensive or non-Nepali participants, or were reviews, case reports or conference abstracts. We did the forward and backward citation tracking for the remaining 12 studies and identified two additional records [43,44]. No additional eligible studies were found in Nepalese journals and on websites of the Nepali Government, professional and regulatory organisation, and national and international agencies. Finally, we included 14 studies [43-56] for qualitative synthesis (see Fig 2). None of the studies were included in the quantitative synthesis of effect sizes because of the significant differences in their aims, methods, interventions/exposures and outcome measures. 


\section{Study characteristics}

Most of the included studies were conducted in either province 3 (Kathmandu and its periphery, $n=8$ ) or province 4 (Kaski, $n=4$ ) or province 1 (Sunsari, $n=2$ ). The numbers of studies conducted in hospital $(n=8)$ and community $(n=6)$ settings were nearly equal. All the community-based studies included participants from the peri-urban $(n=3)$ and urban $(n=3)$ areas. Only a study conducted in Acham (hospital and community-based) included participants from a rural area [47]. Half of the studies were completed in 2015 or later; and more than half of the studies assessed the barriers and enablers of hypertension treatment and control [51-56]. They applied qualitative methods $(n=3)$ [52-54], quantitative methods $(n=4)[51,56]$ and mixed methods $(n=1)$ [55]. The majority of these studies investigated hypertension treatment as an outcome of interest (Table 1). Two studies also discussed adherence to antihypertensive medications [56]. Most studies collected data from hypertensive participants, except one study that interviewed community health workers to explore the barriers and enablers in utilising healthcare among the patients [54].

Six of the included studies that assessed the effectiveness of hypertension treatment and control strategies [45-50] were prospective comparative studies $(n=2)[49,50]$, randomised trials $(n=2)[46,48]$ and uncontrolled before and after studies $(n=2)[45,47]$. Five out of these six studies reported systolic and diastolic blood pressure as outcome measures. The studies tested the effectiveness of health education [45-49] and combined, antihypertensive medication and yoga [48] interventions (Table 2).

The total number of participants in the included studies was 2854 , with the individual sample sizes ranging from $n=13$ to $n=1638$. Only two studies applied multivariable analysis and reported adjusted effect sizes $[46,56]$. Most of the qualitative and mixed methods studies (3 out of 4$)$ applied a thematic analysis. Three studies $[46,47,52]$ reported non-response rates, and they ranged between $9 \%$ and $27.8 \%$.

\section{Study quality}

In quality assessment, 10 studies received three or more stars, suggesting they were of fair or good methodological quality (Additional file 2). Only two out of 11 quantitative studies $[46,56]$ adjusted for confounding.

\section{Barriers and enablers of hypertension treatment and control}

\section{Analysis of qualitative studies}

We identified several themes on barriers to hypertension treatment and control discussed in the qualitative studies. We categorised them into three major domains: HS excluding provider and patient, providers and individual-level barriers (see Table 3). The unaffordability of health services [52], lack of human resources (primarily in rural areas) [54] and the unavailability of diagnostic tools [54] were the most often cited HS barriers.

All qualitative studies discussed the gap in communication between providers and patients that impeded medication adherence and routine follow up. Health care providers failed to deliver clear information to patients regarding medication dosage and duration, behaviour modification and need for routine monitoring. A hypertensive male participant from the study conducted by Shrestha et al. [52] complained that the doctor did not explain enough about his condition.

"..... After check-up, I was told to take medicine. .....I was not told anything. So, I asked people who have heart disease to get the information regarding what food to eat, which food increases it, and which food controls pressure." [52]

A 55 years old participant with uncontrolled hypertension from a study in Kathmandu reported not visiting the doctor for one and half years since her last visit [55] as the doctor did not require for regular visits.

"I have not gone for follow-up. I am following the same regimen from last one and a half years. My doctor told me to visit him only if I had problems" [55]

In addition, other provider-related factors affecting hypertension treatment and control were: health worker's lack of interest in counselling for lifestyle modifications [52-55]; long waiting hours for the appointment [52, 55]; lack of national guidelines in hypertension treatment [55]; and provider's negative behaviours [52].

A wide variety of themes evolved from the qualitative analysis of the findings on patient's beliefs and practices that affect hypertension treatment and control (table 3). The factors impeding initiation of anti-hypertensive treatment were poor help-seeking behaviours [54] and reluctance to take medication due to perceived side effects and fear of long-term use $[52,55]$. Other factors related mostly to treatment adherence and lack of routine monitoring of patients $[54$, 55].

Three studies discussed facilitating factors for improved hypertension treatment. These factors were: access to hypertension care [54], treatment adherence [52], patient's motivation to control hypertension [52] and family support [52, 53].

\section{Analysis of quantitative studies}

Five studies reported findings based on quantitative data. The studies identified the factors associated with hypertension treatment, adherence and control (Table 4). Affordability of the medication was associated with treatment adherence [56]. At the level of the provider, prescribing more than one type of pill was 
associated with greater non-adherence [56]. Similarly, long waiting hours (>20 minutes vs $\leq 20$ minutes) and lack of proper counselling from health workers were associated with uncontrolled hypertension [55]. All quantitative studies reported various individual (patient) level factors that were significantly associated with untreated or uncontrolled hypertension or non-adherence to medication. These were: patients' lack of awareness on normal blood pressure target [51, 55]; lack of knowledge about possible complications of hypertension [51]; lost to follow up [55, 56]; non-adherence to medication [51, 55]; and lack of blood pressure monitoring [51].

Only one study discussed enablers separately. The study found that scores of dimensions of illness perception particularly timeline, treatment control and coherence were positively correlated with medication adherence [44]. The higher the participant perceived high blood pressure as a chronic condition (Spearman correlation coefficient $(r)=0.23, p<0.05)$, the better was medication adherence. The more the participant believed that treatment can control the blood pressure $(r=0.51, p<0.05)$, the higher the medication adherence score they had. The better the understanding of hypertension (coherence, $r=0.22, p<0.05$ ), the higher was the medication adherence [44].

\section{Strategies for hypertension treatment and control}

Out of six eligible studies in this category, all studies intervened at the patient level, two studies also investigated the effect of workforce strengthening (training and continuing education for integrated of NCD care) and one study evaluated the impact of new data recording systems at the healthcare centre (Table 5). The most frequently tested antihypertensive strategy was health education for hypertensive patients [45-47, 49], and three out of four studies found it effective in reducing blood pressure. Health education particularly related to lifestyle modification and medication reconciliations was applied as a component of comprehensive blood pressure management strategies [46, 47, 49] or as a single intervention [45]. Two studies [49, 50] also compared hydrochlorothiazide, enalapril and amlodipine as first-line antihypertensive drugs. The reduction in mean systolic and diastolic pressure was significantly higher with enalapril and amlodipine, compared with hydrochlorothiazide $[49,50]$. The post-intervention changes in blood pressure did not vary significantly between enalapril and amlodipine groups after for weeks $[49,50]$. The participant under amlodipine reported more adverse events such as peripheral oedema, shortness of breath and headache than the enalapril group.

One study studied yoga as an adjuvant therapy to medication and compared it with usual care [48]. The yoga group had a significant reduction in both systolic and diastolic blood pressure, compared with the 'medication-only' group after six weeks of follow-up.

One of the two studies that intervened at the level of healthcare providers found a significant improvement in blood pressure amongst their clients. The study trained and involved female community health volunteers for health education, blood pressure monitoring and referral of hypertensive cases. The intervention was effective in reducing blood pressure. The mixed-effect regression coefficient was -4.9 ( $95 \% \mathrm{Cl}:-7.8$ to -2.0$)$ for systolic blood pressure and -2.6 ( $95 \% \mathrm{Cl}$ : -4.6 to -0.7 ) for diastolic blood pressure [46]. One study implemented the intervention program at HS level, by establishing a new digital and electronic health record system along with capacity development for healthcare workers and providing health education to the patients. The intervention had no statistically significant effect on hypertension control [47]

\section{Discussion}

We systematically reviewed 14 studies to identify barriers, enablers and strategies of hypertension treatment and control in Nepal. Eight of them investigated various barriers and enablers within three domains: the HS, health care providers, and patients. The remaining six studies investigated the effectiveness of different hypertension treatment and control strategies, including health education and yoga.

The synthesis of the findings reported in qualitative studies generated two themes on HS-related barriers for hypertension control and treatment. They were the lack of affordable services and HS resources including human and physical assets. Barriers relating to the availability and affordability of hypertension care services are common in low-income countries $[14,16]$. The HS factors are complex and can have a strong influence on health service delivered by the provider and patient's access to care [14]. The unaffordability of the services and financial hardship at the individual level had linkages with poor help-seeking behaviours, non-adherence to medication and an irregular follow-up visit to health centres among hypertensive patients. The result from the quantitative analysis also showed a significant association between high cost of drugs and non-adherence to medication. The odds of not adhering to taking antihypertensive drugs were 5.2 times higher among the patients who reported the cost of medicine as expensive [56]. This study identified the provision of free essential medicines at government health facilities as a single facilitating factor relating to the Nepali HS. Providing free essential antihypertensive medicines at the primary health care centres was supposed to increase access to treatment of hypertension. Some of the calcium channel blockers and beta blockers are freely available at primary health care centres. However, regular, effective and efficient supply of these medicines is uncertain [57]. For example, most of the health facilities (HF) reported unavailability of atenolol (82\% of HF) and amlodipine (90\% of HF) in 2015 [58].

None of the strategies from the selected studies aimed either to minimise the financial burden associated with hypertension treatment or to increase access to hypertension care. Only one study was identified to report the effect of a strategy implemented at the level of the HS through establishing a new hospitalbased health record system, but the strategy failed to show a significant impact on blood pressure control. To increase access to care and minimise excessive health expenditures, different HS financing approaches, including health insurance coverage and co-payments for medication, have been evaluated globally [14]. Nepal recently enacted the National Health Insurance Act 2017 and is moving towards universal health coverage for equitable access to high quality and affordable health care [59]. However, its overall impact on treatment and control of hypertension and its related complications has yet to be studied.

The communication gap between health workers and the patient was one of the most frequently studied barriers associated at provider level. The lack of clear messages on medication, dosage, lifestyle modification, and follow-up visits was reported as causes of non-adherence to medication and irregular follow-up visits, ultimately leading to suboptimal control of blood pressure. A recent study found that less medication (antihypertensive drugs) discussion between 
providers and patients was associated with six-fold increased odds of poor adherence to medication [60]. Jolles et al. also emphasised that effective communication between providers and patients could increase medication adherence and contributes to better control of high blood pressure [61].

Capacity development of the female health community volunteers (FCHV) and involving them for health education, blood pressure monitoring and linking the cases to health services was the only effective intervention implemented at the provider level. FCHV's involvement in screening the high-risk population and monitoring the hypertensive patients is cost-effective [62] and could minimise the burden of exhausted healthcare workers. After a very acclaimed performance on improving maternal and child health [63], new evidence suggests that community health workers could potentially work as the frontline cadres to fight against the burden of NCDs, including hypertension [64]. Task sharing, particularly with other non-physician health workers in understaffed and resource-poor settings, is an effective strategy for the management of hypertension [31]. Additionally, other approaches such as including pharmacists and nurses in a team and providing team-based hypertension care also showed positive effects on controlling high blood pressure [32].

Most of the barriers at the patient level were related to their knowledge, beliefs and practices. Being unaware of the normal blood pressure target, perceived side effects of drugs, fear of long-term use of medication, reluctance to take medicine, self-medication, non-adherence to medication, lack of follow-up visits, lack of blood pressure monitoring and not minimising risky health behaviours were the key barriers to hypertension treatment and control. Similar to our findings, Khatib et al. in their systematic review reported several patient-related barriers to hypertension treatment and control [16]. The authors categorised them as capability barriers (e.g. lack of skills and knowledge), intention and motivation barriers (e.g. lack of motivation to adhere to a treatment, false belief, such as drug dependency) and medication barriers (e.g. self-perceived side effects, taste and dosage), among others [16].

Health education was the most commonly investigated strategy. One study used yoga as an adjuvant therapy to the medication and found that yoga was effective in blood pressure reduction. Globally, barriers relating to patient's knowledge, belief and practices have been tackled effectively using different approaches, such as simplifying the treatment using polypill [35] and increasing adherence to medication, routinely and conveniently monitoring hypertension through home-based blood pressure measurement [36] and providing education interventions to patients and physicians [37]. Future studies should evaluate the effectiveness of these strategies in the context of Nepali HS.

Some limitations of this review stem from the characteristics of the included studies. Although the majority of studies scored three out of five in MMAT checklists, nearly all of them were subject to inadequate reporting of research methods. For example, out of six comparative or intervention studies, three studies did not present clear information on the estimation of the required sample size and participant selection. Furthermore, only two quantitative studies adjusted their analyses for confounding. These methodological limitations of the included studies may have affected their findings and consequently the findings of our review.

A meta-analysis could not be performed due to a large methodological heterogeneity and variation in outcome measures between the included studies. For example, the data on barriers and enablers were extracted from qualitative, quantitative and mixed methods studies. The data on antihypertensive strategies were from prospective comparative studies, randomised trials and uncontrolled before and after studies. The intervention modalities also varied across studies from health education to yoga.

\section{Conclusion And Implications}

This is the first study to systematically investigate barriers, enablers and strategies of hypertension treatment and control in Nepal. The study findings suggest that various factors associated with HS, providers and patients are responsible for poor hypertension care in Nepal. The findings of our review may assist policy makers and other public health stakeholders in designing future interventions for addressing barriers to hypertension treatment and control.

One example is promoting health education through female community health volunteers (FCHV) that has shown a positive effect in reducing blood pressure. However, more tailored and theory-driven research on the effectiveness of health education interventions is required to confirm the finding. Similarly, trial data available in Nepal are not sufficient to conclude that yoga is an effective antihypertensive therapy. Further large-scale studies are required to evaluate the effectiveness of yoga in hypertension treatment and control.

\section{Declarations}

\section{Availability of data and materials}

All data generated or analysed during this study are included in this published article and its additional files.

\section{Acknowledgements}

This article is a part of a PhD project of the first author, RRD, supervised by MdC (principal supervisor) and ZP (associate supervisor).

\section{Funding}

RRD received a stipend as a PhD student at Victoria University, Australia, which was funded by the Australian Government Research Training Program Scholarship.

\section{Authors' Contributions}


RRD developed the study protocol, screened the records, extracted the data, assessed the quality of included studies, interpreted the findings and prepared the first draft of the manuscript. ARP screened the records, extracted the data, assessed the quality of included studies, and assisted in interpreting the findings.

NS assisted in assessing the quality of the selected studies. ZP and MdC reviewed the study protocol. All authors contributed to writing the manuscript and its revisions. All authors read and approved the final manuscript.

\section{Ethics declarations}

Not applicable

\section{Consent for publication}

Not applicable

\section{Competing interests}

None

\section{Abbreviations}

\begin{tabular}{ll} 
CI & Confidence Interval \\
\hline FCHV & Female health community volunteer \\
\hline HF & Health facility \\
\hline HS & Health system (without provider and patient) \\
\hline LMICs & Low- and middle-income countries \\
MMAT & Mixed Methods Appraisal Tool \\
\hline
\end{tabular}

NCDs Non-communicable diseases

\section{References}

1. Political declaration of the High-level Meeting of the General Assembly on the Prevention and Control of Non-communicable Diseases [https://www.who.int/nmh/events/un_ncd_summit2011/political_declaration_en.pdf]

2. Wozniak G, Khan T, Gillespie C, Sifuentes L, Hasan O, Ritchey M, Kmetik K, Wynia M: Hypertension Control Cascade: A Framework to Improve Hypertension Awareness, Treatment, and Control. J Clin Hypertens (Greenwich) 2016, 18(3):232-239.

3. Mills KT, Bundy JD, Kelly TN, Reed JE, Kearney PM, Reynolds K, Chen J, He J: Global Disparities of Hypertension Prevalence and Control: A Systematic Analysis of Population-Based Studies From 90 Countries. Circulation 2016, 134(6):441-450.

4. Gupta R, Kaur M, Islam S, Mohan V, Mony P, Kumar R, Kutty VR, Iqbal R, Rahman O, Deepa M et al: Association of Household Wealth Index, Educational Status, and Social Capital with Hypertension Awareness, Treatment, and Control in South Asia. Am J Hypertens 2017, 30(4):373-381.

5. Karmacharya BM, Koju RP, LoGerfo JP, Chan KCG, Mokdad AH, Shrestha A, Sotoodehnia N, Fitzpatrick AL: Awareness, treatment and control of hypertension in Nepal: findings from the Dhulikhel Heart Study. Heart Asia 2017, 9(1):1.

6. Mehata S, Shrestha N, Mehta R, Vaidya A, Rawal LB, Bhattarai N, Mishra SR: Prevalence, awareness, treatment and control of hypertension in Nepal: data from nationally representative population-based cross-sectional study. J Hypertens 2018, 36(8):1680-1688.

7. Neupane D, Shrestha A, Mishra SR, Bloch J, Christensen B, McLachlan CS, Karki A, Kallestrup P: Awareness, Prevalence, Treatment, and Control of Hypertension in Westem Nepal. Am J Hypertens 2017, 30(9):907-913.

8. Dhungana RR, Pandey AR, Bista B, Joshi S, Devkota S: Prevalence and Associated Factors of Hypertension: A Community-Based Cross-Sectional Study in Municipalities of Kathmandu, Nepal. Int J Hypertens 2016, 2016:1656938.

9. Khanal MK, Dhungana RR, Bhandari P, Gurung Y, Paudel KN: Prevalence, associated factors, awareness, treatment, and control of hypertension: Findings from a cross sectional study conducted as a part of a community based intervention trial in Surkhet, Mid-western region of Nepal. PLOS One 2017, 12(10):e0185806.

10. Mishra SR, Ghimire S, Shrestha N, Shrestha A, Virani SS: Socio-economic inequalities in hypertension burden and cascade of services: nationwide crosssectional study in Nepal. J Hum Hypertens 2019.

11. Mohan S, Campbell N, Chockalingam A: Management of hypertension in low and middle income countries: Challenges and opportunities. Prevention and Control 2005, 1(4):275-284.

12. Legido-Quigley H, Naheed A, de Silva HA, Jehan I, Haldane V, Cobb B, Tavajoh S, Chakma N, Kasturiratne A, Siddiqui S et al: Patients' experiences on accessing health care services for management of hypertension in rural Bangladesh, Pakistan and Sri Lanka: A qualitative study. PLoS One 2019, 14(1):e0211100. 
13. Belizan M, Alonso JP, Nejamis A, Caporale J, Copo MG, Sanchez M, Rubinstein A, Irazola V: Barriers to hypertension and diabetes management in primary health care in Argentina: qualitative research based on a behavioral economics approach. Trans/ Behav Med 2019.

14. Maimaris W, Paty J, Perel P, Legido-Quigley H, Balabanova D, Nieuwlaat R, McKee M: The influence of health systems on hypertension awareness, treatment, and control: a systematic literature review. PLoS Med 2013, 10(7):e1001490.

15. Coca A, Lopez-Jaramillo P, Thomopoulos C, Zanchetti A, Latin American Society of H: Best antihypertensive strategies to improve blood pressure control in Latin America: position of the Latin American Society of Hypertension. J Hypertens 2018, 36(2):208-220.

16. Khatib R, Schwalm JD, Yusuf S, Haynes RB, McKee M, Khan M, Nieuwlaat R: Patient and healthcare provider barriers to hypertension awareness, treatment and follow up: a systematic review and meta-analysis of qualitative and quantitative studies. PLoS One 2014, 9(1):e84238.

17. Pound P, Britten N, Morgan M, Yardley L, Pope C, Daker-White G, Campbell R: Resisting medicines: a synthesis of qualitative studies of medicine taking. Social science \& medicine (1982) 2005, 61(1):133-155.

18. Bramley TJ, Nightengale BS, Frech-Tamas F, Gerbino PP: Relationship of blood pressure control to adherence with antihypertensive monotherapy in 13 managed care organizations. Journal of Managed Care Pharmacy 2006, 12(3):239-245.

19. Hashmi SK, Afridi MB, Abbas K, Sajwani RA, Saleheen D, Frossard PM, Ishaq M, Ambreen A, Ahmad U: Factors associated with adherence to antihypertensive treatment in Pakistan. PLoS One 2007, 2(3):e280.

20. Randy Wexler M, Pleister A, David Feldman M: Barriers to blood pressure control as reported by African American patients. Journal of the National Medical Association 2009, 101(6):597.

21. Elder K, Ramamonjiarivelo Z, Wiltshire J, Piper C, Horn WS, Gilbert KL, Hullett S, Allison J: Trust, medication adherence, and hypertension control in Southern African American men. American Journal of Public Health 2012, 102(12):2242-2245.

22. Marshall IJ, Wolfe CD, McKevitt C: Lay perspectives on hypertension and drug adherence: systematic review of qualitative research. 2012.

23. Lin JS, O'Connor E, Evans CV, Senger CA, Rowland MG, Groom HC: Behavioral counseling to promote a healthy lifestyle in persons with cardiovascular risk factors: a systematic review for the US Preventive Services Task Force. Annals of internal medicine 2014, 161(8):568-578.

24. Risso-Gill I, Balabanova D, Majid F, Ng KK, Yusoff K, Mustapha F, Kuhlbrandt C, Nieuwlaat R, Schwalm J-D, McCready T: Understanding the modifiable health systems barriers to hypertension management in Malaysia: a multi-method health systems appraisal approach. $B M C$ health services research 2015, 15(1):254.

25. Jin J, Sklar GE, Oh VMS, Li SC: Factors affecting therapeutic compliance: A review from the patient's perspective. Therapeutics and clinical risk management 2008, 4(1):269.

26. Oliveria SA, Lapuerta P, McCarthy BD, L'Italien GJ, Berlowitz DR, Asch SM: Physician-Related Barriers to the Effective Management of Uncontrolled Hypertension. JAMA Internal Medicine 2002, 162(4):413-420.

27. Borzecki AM, Oliveria SA, Berlowitz DR: Barriers to hypertension control. Am Heart J 2005, 149(5):785-794.

28. Al-Noumani H, Wu JR, Barksdale D, Sherwood G, AlKhasawneh E, Knafl G: Health beliefs and medication adherence in patients with hypertension: A systematic review of quantitative studies. Patient Educ Couns 2019, 102(6):1045-1056.

29. Shrestha S, Shrestha A, Koju RP, LoGerfo JP, Karmacharya BM, Sotoodehnia N, Fitzpatrick AL: Barriers and facilitators to treatment among patients with newly diagnosed hypertension in Nepal. Heart Asia 2018, 10(2):e011047.

30. Vedanthan R, Tuikong N, Kofler C, Blank E, Kamano JH, Naanyu V, Kimaiyo S, Inui TS, Horowitz CR, Fuster V: Barriers and Facilitators to Nurse Management of Hypertension: A Qualitative Analysis from Western Kenya. Ethn Dis 2016, 26(3):315-322.

31. Anand TN, Joseph LM, Geetha AV, Prabhakaran D, Jeemon P: Task sharing with non-physician health-care workers for management of blood pressure in low-income and middle-income countries: a systematic review and meta-analysis. Lancet Glob Health 2019, 7(6):e761-e771.

32. Proia KK, Thota AB, Njie GJ, Finnie RK, Hopkins DP, Mukhtar Q, Pronk NP, Zeigler D, Kottke TE, Rask KJ: Team-based care and improved blood pressure control: a community guide systematic review. American journal of preventive medicine 2014, 47(1):86-99.

33. Zhang D, Pan X, Li S, Liang D, Hou Z, Li Y, Shi L: Impact of the National Essential Public Health Services Policy on Hypertension Control in China. Am J Hypertens 2017, 31(1):115-123.

34. Rochlani Y, Khan MH, Banach M, Aronow WS: Are two drugs better than one? A review of combination therapies for hypertension. Expert opinion on pharmacotherapy 2017, 18(4):377-386.

35. Coca A, Agabiti-Rosei E, Cifkova R, Manolis AJ, Redón J, Mancia G: The polypill in cardiovascular prevention: evidence, limitations and perspectiveposition paper of the European Society of Hypertension. Journal of hypertension 2017, 35(8):1546-1553.

36. Park S, Buranakitjaroen P, Chen CH, Chia YC, Divinagracia R, Hoshide S, Shin J, Siddique S, Sison J, Soenarta AA et al: Expert panel consensus recommendations for home blood pressure monitoring in Asia: the Hope Asia Network. J Hum Hypertens 2018, 32(4):249-258.

37. Fahey T, Schroeder K, Ebrahim S: Educational and organisational interventions used to improve the management of hypertension in primary care: a systematic review. Br J Gen Pract 2005, 55(520):875-882

38. Population, total - Nepal [https://data.worldbank.org/indicator/SP.POP.TOTL?locations=NP]

39. Central Bureau Of Statistics (CBS) Nepal: National population and housing census 2011. In. Kathmandu: CBS; 2012.

40. Nepal's Community-based Health System Model: Structure, Strategies, and Learning [https://www.advancingpartners.org/resources/technicalbriefs/nepal-community-based-health-system-

model\#: :text=Nepal's\%20public\%20health\%20system\%20is,cost\%20of\%20services\%20for\%20patients.\&text=Health\%20policy\%20is\%20developed\%2C\% 
41. Moher D, Shamseer L, Clarke M, Ghersi D, Liberati A, Petticrew M, Shekelle P, Stewart LA: Preferred reporting items for systematic review and meta-analysis protocols (PRISMA-P) 2015 statement. Systematic reviews 2015, 4(1):1.

42. Ouzzani M, Hammady H, Fedorowicz Z, Elmagarmid A: Rayyan-a web and mobile app for systematic reviews. Systematic Reviews $2016,5: 210$.

43. Khan GM, Thapa RK, Khakurel A, Shrestha G, Katila N, Bhurtel S: Medication adherence and blood pressure control among hypertensive patients of Pokhara valley. Journal of Health and Allied Sciences 2013, 3(1):64-67.

44. Maharjan S: Illness perception and treatment adherence among patients with hypertension in Nepal. Thailand: Prince of Songkla University; 2016.

45. Sharma S, KC B, Alrasheedy AA, Kaundinnyayana A, Khanal A: Impact of community pharmacy-based educational intervention on patients with hypertension in Western Nepal. Australasian Medical Journal 2014, 7(7):304-313.

46. Neupane D, McLachlan CS, Mishra SR, Olsen MH, Perry HB, Karki A, Kallestrup P: Effectiveness of a lifestyle intervention led by female community health volunteers versus usual care in blood pressure reduction (COBIN): an open-label, cluster-randomised trial. The Lancet Global Health 2018, 6(1):e66-e73.

47. Kumar A, Schwarz D, Acharya B, Agrawal P, Aryal A, Choudhury N, Citrin D, Dangal B, Deukmedjian G, Dhimal M et al: Designing and implementing an integrated non-communicable disease primary care intervention in rural Nepal. BMJ Glob Health 2019, 4(2):e001343.

48. Khadka R, Paudel BH, Sharma V, Kumar S, Bhattacharya N: Effect of yoga on cardiovascular autonomic reactivity in essential hypertensive patients. Health Renaissance 2010, 8(2):102-109.

49. Humagain S, Koju R: Efficacy of different antihypertensive drugs among Nepalese population. Kathmandu University Medical Journal 2015, 13(51):212215.

50. Alam K, Khan GM, Koju R, Thapa P: Comparative study on anti-hypertensive effects of amlodipine and enalapril in primary hypertension. Pharmacologyonline 2007, 1:516-528.

51. Simkhada R: Study on blood pressure control status and predictors of uncontrolled blood pressure among hypertensive patients under medication. Nepal Medical College journal : NMCJ 2012, 14(1):56-59

52. Shrestha S, Shrestha A, Koju RP, Logerfo JP, Karmacharya BM, Sotoodehnia N, Fitzpatrick AL: Barriers and facilitators to treatment among patients with newly diagnosed hypertension in Nepal. Heart Asia 2018, 10(2).

53. Oli N, Vaidya A, Subedi M, Krettek A: Experiences and perceptions about cause and prevention of cardiovascular disease among people with cardiometabolic conditions: findings of in-depth interviews from a peri-urban Nepalese community. Global health action 2014, 7(1):24023-24023.

54. Khanal S, Veerman L, Nissen L, Hollingworth S: Use of healthcare services by patients with non-communicable diseases in Nepal: A qualitative study with healthcare providers. Journal of Clinical and Diagnostic Research 2017, 11(6):LC01-LC05.

55. Devkota S, Dhungana RR, Pandey AR, Bista B, Panthi S, Thakur KK, Gajurel RM: Barriers to Treatment and Control of Hypertension among Hypertensive Participants: A Community-Based Cross-sectional Mixed Method Study in Municipalities of Kathmandu, Nepal. Front Cardiovasc Med 2016, 3:26.

56. Bhandari B, Bhattarai M, Bhandari M, Ghimire A, Pokharel PK, Morisky DE: Adherence to Antihypertensive Medications: Population Based Follow up in Eastem Nepal. Journal of Nepal Health Research Council 2015, 13(29):38-42.

57. Prasai DP: A review of studies on Nepal's national free health care programme In.: Minstry of Health and Population; 2013.

58. Ministry of Health, Nepal, New ERA, Nepal, Nepal Health Sector Support Program (NHSSP), ICF International: Nepal Health Facility Survey 2015 Final Report. In. Kathmandu, Nepal: Ministry of Health, Nepal; 2017.

59. Kandel N: Nepal Health Insurance Bill: Possible Challenges and Way Forwards. Journal of the Nepal Medical Association 2018, 56(210).

60. Schoenthaler A, Knafl GJ, Fiscella K, Ogedegbe G: Addressing the Social Needs of Hypertensive Patients: The Role of Patient-Provider Communication as a Predictor of Medication Adherence. Circ Cardiovasc Qual Outcomes 2017, 10(9):e003659.

61. Jolles EP, Clark AM, Braam B: Getting the message across: opportunities and obstacles in effective communication in hypertension care. $J$ Hypertens 2012, 30(8):1500-1510.

62. Neupane D, Krishnan A, Kallestrup P, Karki A, Olsen MH, Finkelstein EA: Female community health volunteer-led lifestyle intervention is a highly costeffective, low-cost and scalable solution for blood pressure control in Nepal. Circulation 2019, 139.

63. Perry HB, Zulliger R, Rogers MM: Community health workers in low-, middle-, and high-income countries: an overview of their history, recent evolution, and current effectiveness. Annu Rev Public Health 2014, 35:399-421.

64. Khetan AK, Purushothaman R, Chami T, Hejjaji V, Madan Mohan SK, Josephson RA, Webel AR: The Effectiveness of Community Health Workers for CVD Prevention in LMIC. Glob Heart 2017, 12(3):233-243 e236.

\section{Tables}

Table 1. Characteristics of the studies on barriers and enablers of hypertension treatment and control in Nepal 


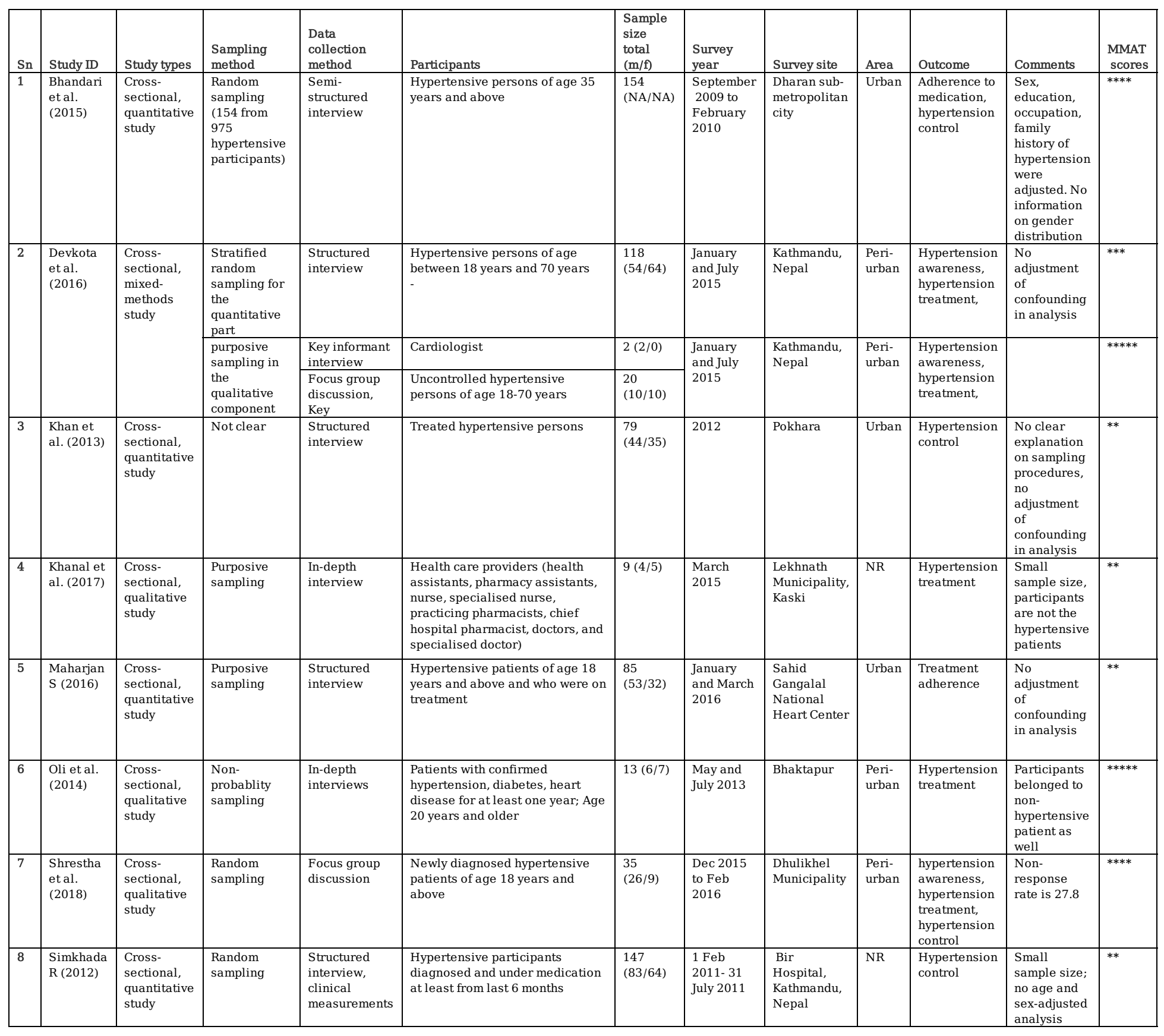

Table 2. Characteristics of the studies on the effectiveness of strategies to improve hypertension treatment and control in Nepal 


\begin{tabular}{|c|c|c|c|c|c|c|c|c|c|}
\hline $\mathrm{Sn}$ & Study ID & Study types & $\begin{array}{l}\text { Study date and } \\
\text { sites }\end{array}$ & Participants & Participant recruitment & Intervention & $\begin{array}{l}\text { Sample size total } \\
\text { (treatment/control) }\end{array}$ & Outcome & $\begin{array}{l}\text { MMAT } \\
\text { score }\end{array}$ \\
\hline 1 & $\begin{array}{l}\text { Alam et } \\
\text { al. (2007) }\end{array}$ & $\begin{array}{l}\text { Prospective } \\
\text { comparative } \\
\text { study }\end{array}$ & $\begin{array}{l}\text { Sep 2005 to July } \\
\text { 2006; Kathmandu } \\
\text { University } \\
\text { Teaching } \\
\text { Hospital, } \\
\text { Dhulikhel and } \\
\text { Saheed Gangalal } \\
\text { National Heart } \\
\text { Center, } \\
\text { Kathmandu } \\
\end{array}$ & $\begin{array}{l}\text { Hypertensive } \\
\text { patients } \\
\text { diagnosed } \\
\text { newly or not } \\
\text { taking } \\
\text { medication, of } \\
\text { any age }\end{array}$ & $\begin{array}{l}\text { Participants were selected and } \\
\text { divided them into two groups: } \\
\text { amlodipine and enalapril group }\end{array}$ & $\begin{array}{l}\text { Amlodipine or enalapril for four } \\
\text { weeks }\end{array}$ & $72(36 / 36)$ & $\begin{array}{l}\text { Systolic } \\
\text { blood } \\
\text { pressure } \\
\text { Diastolic } \\
\text { blood } \\
\text { pressure }\end{array}$ & $* * *$ \\
\hline 2 & $\begin{array}{l}\text { Humagain } \\
\text { et al. } \\
\text { (2015) }\end{array}$ & $\begin{array}{l}\text { Prospective } \\
\text { comparative } \\
\text { study }\end{array}$ & $\begin{array}{l}\text { January } 2015 \text { to } \\
\text { April 2015; } \\
\text { Dhulikhel } \\
\text { Hospital, } \\
\text { Kathmandu } \\
\text { University Nepal }\end{array}$ & $\begin{array}{l}\text { Hypertensive } \\
\text { patients of } 40- \\
80 \text { years of age } \\
\text { attending } \\
\text { cardiology } \\
\text { OPD }\end{array}$ & $\begin{array}{l}\text { Enrolled all the hypertensive } \\
\text { patients who attended the study } \\
\text { site during the study period and } \\
\text { divided them into three groups } \\
\text { based on the three } \\
\text { antihypertensive medication they } \\
\text { used: hydrochlorothiazide } 25 \mathrm{mg} \\
\text { or amlodipine } 5 \text { mg or enalapril } 5 \\
\text { mg }\end{array}$ & $\begin{array}{l}\text { Participants received an } \\
\text { antihypertensive medication (any of } \\
\text { hydrochlorothiazide } 25 \mathrm{mg} \text { or } \\
\text { Amlodipine } 5 \mathrm{mg} \text { or Enalapril } 5 \mathrm{mg} \text { ) } \\
\text { and health education. }\end{array}$ & 172 (NA/NA) & $\begin{array}{l}\text { Systolic } \\
\text { blood } \\
\text { pressure } \\
\text { Diastolic } \\
\text { blood } \\
\text { pressure }\end{array}$ & $* * *$ \\
\hline 3 & $\begin{array}{l}\text { Khadka et } \\
\text { al. (2010) }\end{array}$ & $\begin{array}{l}\text { Randomised } \\
\text { controlled } \\
\text { trial }\end{array}$ & $\begin{array}{l}\text { 2000-2002; Yoga } \\
\text { and lifestyle } \\
\text { clinics, } \\
\text { Department of } \\
\text { Physiology, } \\
\text { BPKIHS }\end{array}$ & $\begin{array}{l}\text { Essential } \\
\text { hypertensive } \\
\text { patients of } 30 \text { - } \\
60 \text { years of } \\
\text { age, without } \\
\text { diabetes }\end{array}$ & $\begin{array}{l}\text { Purposively selected the } \\
\text { participants and Systematically } \\
\text { randomised them into yoga and } \\
\text { control group }\end{array}$ & $\begin{array}{l}\text { Treatment group participants } \\
\text { underwent for yoga practice } \\
\text { scheduled for half an hour at least } \\
\text { for } 6 \text { days in a week for } 6 \text { weeks; } \\
\text { yogic practices were strengthening } \\
\text { exercise ( } 5 \text { min), yogic asanas ( } 6-7 \\
\text { minutes), Shavasan ( } 5 \text { minutes), } \\
\text { meditation ( } 5 \text { minutes), pranayam } \\
\text { (4 minutes) }\end{array}$ & $14(7 / 7)$ & $\begin{array}{l}\text { Systolic } \\
\text { blood } \\
\text { pressure } \\
\text { Diastolic } \\
\text { blood } \\
\text { pressure }\end{array}$ & $* * *$ \\
\hline 4 & $\begin{array}{l}\text { Kumar et } \\
\text { al. (2019) }\end{array}$ & $\begin{array}{l}\text { Uncontrolled } \\
\text { Before and } \\
\text { After study }\end{array}$ & $\begin{array}{l}\text { 1 December } \\
\text { 2016-31 May } \\
\text { 2018; Achham, } \\
\text { Nepal }\end{array}$ & $\begin{array}{l}\text { Hypertensive } \\
\text { patients of age } \\
18 \text { years and } \\
\text { above }\end{array}$ & $\begin{array}{l}\text { Among the } 488 \text { hypertensive } \\
\text { patients enrolled in the NCD } \\
\text { program, the study selected } 86 \% \\
\text { ( } 340 \text { out of } 488 \text { ) patients (all) } \\
\text { with at least two follow up visits } \\
\text { and having at least } 12 \text { week } \\
\text { interval between baseline and } \\
\text { endline }\end{array}$ & $\begin{array}{l}\text { Intervention includes NCD } \\
\text { management capacity development } \\
\text { for healthcare workers, } \\
\text { establishment of digital and } \\
\text { electronic health records in the } \\
\text { centre and individual (patient) } \\
\text { level counselling for preventive and } \\
\text { treatment of NCDs. }\end{array}$ & $340(340 /-)$ & $\begin{array}{l}\text { Hypertension } \\
\text { control }\end{array}$ & $* * *$ \\
\hline 5 & $\begin{array}{l}\text { Neupane } \\
\text { et al. } \\
(2018)\end{array}$ & $\begin{array}{l}\text { Clustered } \\
\text { randomised } \\
\text { trial }\end{array}$ & $\begin{array}{l}\text { 2015-2016; } \\
\text { Lekhanath } \\
\text { municipality, } \\
\text { Kaski }\end{array}$ & $\begin{array}{l}\text { General } \\
\text { population } \\
\text { (normotensive, } \\
\text { pre- } \\
\text { hypertensive, } \\
\text { hypertensive) } \\
\text { of 25-65 years } \\
\text { of age }\end{array}$ & $\begin{array}{l}\text { Participants were selected from } \\
14 \text { clusters. The municipality was } \\
\text { divided into } 15 \text { clusters out of } \\
\text { which } 14 \text { clustered were } \\
\text { randomised into intervention and } \\
\text { control group; } 1: 1 \text { ratio. }\end{array}$ & $\begin{array}{l}\text { The treatment group participants } \\
\text { received health education on major } \\
\text { NCD risk factors, had their blood } \\
\text { pressure measurement and were } \\
\text { referred (only for hypertensive } \\
\text { participants) to health centre by the } \\
\text { trained Female Community Health } \\
\text { Volunteer in every four } \\
\text { months/year. }\end{array}$ & $1638(939 / 699)$ & $\begin{array}{l}\text { Systolic } \\
\text { blood } \\
\text { pressure } \\
\text { Diastolic } \\
\text { blood } \\
\text { pressure }\end{array}$ & $* * * *$ \\
\hline 6 & $\begin{array}{l}\text { Sharma et } \\
\text { al. (2014) }\end{array}$ & $\begin{array}{l}\text { Uncontrolled } \\
\text { Before and } \\
\text { After study }\end{array}$ & $\begin{array}{l}\text { August 2012 to } \\
\text { April 2013; } \\
\text { Sankalpa } \\
\text { Pharmacy, Kaski, } \\
\text { Nepal }\end{array}$ & $\begin{array}{l}\text { Hypertensive } \\
\text { patients of } 31 \\
\text { years and } \\
\text { above } \\
\text { attending the } \\
\text { pharmacist run } \\
\text { hypertension } \\
\text { clinic }\end{array}$ & $\begin{array}{l}\text { Enrolled all the eligible } \\
\text { hypertensive patients who } \\
\text { attended the study site }\end{array}$ & $\begin{array}{l}\text { Healthcare workers (pharmacist) } \\
\text { led one- to one counselling - } \\
\text { contained three counselling } \\
\text { session at } 0 \text { date, two months and } \\
\text { four months. The contents of } \\
\text { counselling were lifestyle } \\
\text { modification, treatment, and control } \\
\text { of hypertension }\end{array}$ & $50(50 /-)$ & $\begin{array}{l}\text { Systolic } \\
\text { blood } \\
\text { pressure } \\
\text { Diastolic } \\
\text { blood } \\
\text { pressure }\end{array}$ & $* * *$ \\
\hline
\end{tabular}

Table 3. Barriers and enablers of hypertension treatment and control in Nepal

\begin{tabular}{|l|l|l|}
\hline Domain & Barriers & Enablers \\
\hline $\begin{array}{l}\text { Health } \\
\text { system } \\
\text { (excluding } \\
\text { provider and } \\
\text { patient) }\end{array}$ & Unaffordable services; Lack of human resources and diagnostic tools & $\begin{array}{l}\text { Free essential medicines at health } \\
\text { centre }\end{array}$ \\
$\begin{array}{l}\text { Health care } \\
\text { providers }\end{array}$ & $\begin{array}{l}\text { Communication gap between patients and providers regarding medication use } \\
\text { and follow-up visits; No proper counselling on lifestyle modifications; Long } \\
\text { waiting hours; Lack of national guidelines for hypertension treatment; } \\
\text { Provider's negative behaviours }\end{array}$ & - \\
\hline $\begin{array}{l}\text { Patient } \\
\text { Ron-adherence; Lack of routine follow-up visits; Poor help seeking behaviours; } \\
\text { side effects of change behaviours; Reluctance to take medication; Perceived } \\
\text { support; Financial hardensivensive medication; Self-medication; Lack of family }\end{array}$ & $\begin{array}{l}\text { Family support; Perceived seriousness } \\
\text { of the illness; Self-motivation; Use of } \\
\text { reminders for medication; Use of } \\
\text { medication containers }\end{array}$ \\
\hline
\end{tabular}

Table 4. Barriers reported in quantitative studies 


\begin{tabular}{|c|c|c|}
\hline Study ID & Domain & Findings \\
\hline \multirow[t]{3}{*}{ Bhandari et al. (2015) } & $\begin{array}{l}\text { Health system } \\
\text { related }\end{array}$ & $\begin{array}{l}\text { Exposure: high cost of medicine (expensive vs. affordable) } \\
\text { Outcome: non-adherence } \\
\text { Odds ratio }=5.2 ; 95 \% \text { CI: } 1.1-23.9\end{array}$ \\
\hline & Provider related & $\begin{array}{l}\text { Exposure: multi-pills (more than one vs. one antihypertensive drug prescription) } \\
\text { Outcome: non-adherence } \\
\text { Odds ratio }=5.3 ; 95 \% \text { CI: } 1.2-23.7\end{array}$ \\
\hline & Patient related & $\begin{array}{l}\text { Exposure: lost to follow up (irregular vs regular) } \\
\text { Outcome: non-adherence } \\
\text { Odds ratio }=6.4 ; 95 \% \text { CI: } 1.2-33.4\end{array}$ \\
\hline \multirow[t]{6}{*}{ Devkota et al. (2016) } & $\begin{array}{l}\text { Health system } \\
\text { related }\end{array}$ & - \\
\hline & Provider related & $\begin{array}{l}\text { Exposure: long waiting hours ( }>20 \text { minutes vs. } \leq 20 \text { minutes) } \\
\text { Outcome: uncontrolled hypertension } \\
\text { Odds ratio = 2.7; } 95 \% \text { CI: } 1.1-6.8 \text {; }\end{array}$ \\
\hline & & $\begin{array}{l}\text { Exposure: no health education from health worker } \\
\text { Outcome: uncontrolled hypertension } \\
\text { Odds ratio }=2.6,95 \% \text { CI } 1.2-6.4\end{array}$ \\
\hline & Patient related & $\begin{array}{l}\text { Exposure: lack of awareness of blood pressure target } \\
\text { Outcome: untreated hypertension } \\
\text { Odds ratio = 3.2; } 95 \% \text { CI: } 1.3-8.2 \text {; }\end{array}$ \\
\hline & & $\begin{array}{l}\text { Exposure: nonadherence to medication } \\
\text { Outcome: uncontrolled hypertension } \\
\text { Odds ratio = 8.8, 95\% CI: 3.3-23.4; }\end{array}$ \\
\hline & & $\begin{array}{l}\text { Exposure: lost to follow-up } \\
\text { Outcome: uncontrolled hypertension } \\
\text { Odds ratio }=3.3,95 \% \text { CI: } 1.2-9.1\end{array}$ \\
\hline \multirow[t]{6}{*}{ Simkhada (2012) } & $\begin{array}{l}\text { Health system } \\
\text { related }\end{array}$ & - \\
\hline & Provider related & - \\
\hline & Patient related & $\begin{array}{l}\text { Exposure: lack of awareness on blood pressure target } \\
\text { Outcome: uncontrolled hypertension } \\
\text { Odds ratio = } 2.8,95 \% \text { CI: } 1.3-6.1 \text {; }\end{array}$ \\
\hline & & $\begin{array}{l}\text { Exposure: lack of awareness on BP complication } \\
\text { Outcome: uncontrolled hypertension } \\
\text { Odds ratio = 3.7, 95\% CI: } 1.5-9.1\end{array}$ \\
\hline & & $\begin{array}{l}\text { Exposure: nonadherence to medication } \\
\text { Outcome: uncontrolled hypertension } \\
\text { Odds ratio = 3.3, 95\%CI: 1.5-7.1; }\end{array}$ \\
\hline & & $\begin{array}{l}\text { Exposure: lack of blood pressure monitoring } \\
\text { Outcome: uncontrolled hypertension } \\
\text { Odds ratio }=2.9,95 \% \text { CI: } 1.1-8.1\end{array}$ \\
\hline
\end{tabular}

Table 5. Findings of the studies on the effectiveness of strategies to improve hypertension treatment and control in Nepal 


\begin{tabular}{|c|c|c|c|c|c|c|}
\hline Study ID & Comparison & $\begin{array}{l}\text { Sample size total } \\
\text { (treatment/control) }\end{array}$ & $\begin{array}{l}\text { Participants } \\
\text { in analysis }\end{array}$ & Outcome & Findings & $\begin{array}{l}\text { Overall } \\
\text { MMAT } \\
\text { score }\end{array}$ \\
\hline \multirow[t]{2}{*}{$\begin{array}{l}\text { Alam et } \\
\text { al. (2007) }\end{array}$} & \multirow[t]{2}{*}{ Enalapril vs amlodipine } & \multirow[t]{2}{*}{$72(36 / 36)$} & \multirow[t]{2}{*}{72} & $\begin{array}{l}\text { Outcome 1: } \\
\text { Systolic blood } \\
\text { pressure }\end{array}$ & $\begin{array}{l}\text { mean (sd) reduced from } 162.1(22.0) \mathrm{mmHg} \text { to } 131.3(11.4) \mathrm{mmHg} \text { in } \\
\text { enalapril group and from } 158.2(16.2) \mathrm{mmHg} \text { to } 132.6(11.7) \mathrm{mmHg} \text { in } \\
\text { amlodipine group }\end{array}$ & \multirow[t]{2}{*}{ *** } \\
\hline & & & & $\begin{array}{l}\text { Outcome 2: } \\
\text { Diastolic blood } \\
\text { pressure }\end{array}$ & $\begin{array}{l}\text { mean (sd) reduced from } 103.1(11.5) \mathrm{mmHg} \text { to } 85.2(8.1) \mathrm{mmHg} \text { in enalapril } \\
\text { group and from } 100.3(7.3) \mathrm{mmHg} \text { to } 87.3(8.4) \mathrm{mmHg} \text { in amlodipine group }\end{array}$ & \\
\hline \multirow[t]{5}{*}{$\begin{array}{l}\text { Humagain } \\
\text { et al. } \\
\text { (2015) }\end{array}$} & \multirow[t]{2}{*}{$\begin{array}{l}\text { Comparison 1: } \\
\text { hydrochlorothiazide } 25 \mathrm{mg} v \mathrm{vs} \\
\text { amlodipine } 5 \mathrm{mg}\end{array}$} & \multirow[t]{2}{*}{$172(\mathrm{NA} / \mathrm{NA})$} & \multirow[t]{2}{*}{172} & $\begin{array}{l}\text { Outcome1: } \\
\text { Systolic blood } \\
\text { pressure }\end{array}$ & $\begin{array}{l}\text { Before and after difference of mean(sd) 14.6(5.1) } \mathrm{mmHg} \text { vs } 21.9(5.9) \mathrm{mmHg} \text {, } \\
\mathrm{p}<0.01\end{array}$ & \multirow[t]{5}{*}{ *** } \\
\hline & & & & $\begin{array}{l}\text { Outcome 2: } \\
\text { Diastolic blood } \\
\text { pressure }\end{array}$ & Before and after difference of mean (sd) $8.8(2.5) \mathrm{mmHg}$ vs $14.2(2.8), \mathrm{p}<0.01$ & \\
\hline & \multirow[t]{2}{*}{$\begin{array}{l}\text { Comparison 2: } \\
\text { hydrochlorothiazide } 25 \mathrm{mg} \text { vs } \\
\text { enalapril } 5 \mathrm{mg}\end{array}$} & \multirow[t]{2}{*}{$172(\mathrm{NA} / \mathrm{NA})$} & \multirow[t]{2}{*}{172} & $\begin{array}{l}\text { Outcome 1: } \\
\text { Systolic blood } \\
\text { pressure }\end{array}$ & $\begin{array}{l}\text { Before and after difference in mean (sd) } 14.6 \text { (5.1) } \mathrm{mmHg} \text { vs } 21.8 \text { (7.4), } \\
\mathrm{p}<0.01\end{array}$ & \\
\hline & & & & $\begin{array}{l}\text { Outcome 2: } \\
\text { Diastolic blood } \\
\text { pressure }\end{array}$ & $\begin{array}{l}\text { Before and after difference in mean (sd) } 8.8(2.5) \mathrm{mmHg} \text { vs } 14.2(2.9) \mathrm{mmHg} \text {, } \\
\mathrm{p}<0.01\end{array}$ & \\
\hline & $\begin{array}{l}\text { Comparison 3: amlodipine } 5 \mathrm{mg} \\
\text { vs enalapril } 5 \mathrm{mg}\end{array}$ & $172(\mathrm{NA} / \mathrm{NA})$ & 172 & $\begin{array}{l}\text { Outcome } 2: \\
\text { Diastolic blood } \\
\text { pressure }\end{array}$ & $\begin{array}{l}\text { Before and after difference in mean (sd) } 14.2(2.8) \mathrm{mmHg} \text { vs } 14.3 \text { (2.9), } \\
\mathrm{p}=0.86\end{array}$ & \\
\hline \multirow[t]{2}{*}{$\begin{array}{l}\text { Khadka et } \\
\text { al. (2010) }\end{array}$} & \multirow[t]{2}{*}{ yoga vs routine care } & \multirow[t]{2}{*}{$14(7 / 7)$} & \multirow[t]{2}{*}{14} & $\begin{array}{l}\text { Outcome 1: } \\
\text { Systolic blood } \\
\text { pressure }\end{array}$ & $\begin{array}{l}\text { Before and after difference in median was } 21 \mathrm{mmHg} \text { in yoga vs } 12 \mathrm{mmHg} \text { in } \\
\text { control group, } \mathrm{p}<0.05\end{array}$ & \multirow[t]{2}{*}{ *** } \\
\hline & & & & $\begin{array}{l}\text { Outcome 2: } \\
\text { Diastolic blood } \\
\text { pressure }\end{array}$ & $\begin{array}{l}\text { Before and after difference in median } 18 \mathrm{mmHg} \text { in yoga group vs } 0 \mathrm{mmHg} \text { in } \\
\text { control group, } \mathrm{p}<0.05\end{array}$ & \\
\hline $\begin{array}{l}\text { Kumar et } \\
\text { al. (2019) }\end{array}$ & $\begin{array}{l}\text { multilevel intervention, no } \\
\text { comparison group }\end{array}$ & $340(340 /-)$ & 340 & $\begin{array}{l}\text { Hypertension } \\
\text { control }\end{array}$ & $\begin{array}{l}\text { No statistically significant difference between baseline and endline } \\
\text { outcome; hypertension control rate decreased from } 75 \% \text { ( } 254 \text { out of } 340 \text { ) to } \\
73 \% \text { ( } 249 \text { out of } 340 \text { ) }\end{array}$ & $* * *$ \\
\hline \multirow[t]{2}{*}{$\begin{array}{l}\text { Neupane } \\
\text { et al. } \\
(2018)\end{array}$} & \multirow[t]{2}{*}{$\begin{array}{l}\text { Health education, blood pressure } \\
\text { monitoring, and referral vs usual } \\
\text { care }\end{array}$} & \multirow[t]{2}{*}{$1638(939 / 699)$} & \multirow[t]{2}{*}{1468} & $\begin{array}{l}\text { Outcome 1: } \\
\text { Systolic blood } \\
\text { pressure }\end{array}$ & $\begin{array}{l}\text { Before and after difference in mean was } 6.47 \mathrm{mmHg} \text { in the intervention vs } \\
2.85 \mathrm{mmHg} \text { in the control group }\end{array}$ & \multirow[t]{2}{*}{ **** } \\
\hline & & & & $\begin{array}{l}\text { Outcome 2: } \\
\text { Diastolic blood } \\
\text { pressure }\end{array}$ & $\begin{array}{l}\text { Before and after difference in mean was } 2.90 \mathrm{mmHg} \text { in the intervention } \\
\text { group vs } 1.11 \mathrm{mmHg} \text { in control group }\end{array}$ & \\
\hline $\begin{array}{l}\text { Sharma et } \\
\text { al. (2014) }\end{array}$ & $\begin{array}{l}\text { Health education, no comparison } \\
\text { group }\end{array}$ & $50(50 /-)$ & 50 & $\begin{array}{l}\text { Outcome } \\
\text { 2: Diastolic } \\
\text { blood pressure }\end{array}$ & The mean (sd) reduced from 104 (9.5) $\mathrm{mmHg}$ to 94.5 (7.7) $\mathrm{mmHg}, \mathrm{p}<0.01$ & *** \\
\hline
\end{tabular}

\section{Additional Files}

Additional file 1:

Search strategies. (DOCX 88 KB)

Additional file 2:

Quality assessment of the selected studies. (xlsx $13 \mathrm{~KB}$ )

\section{Figures}




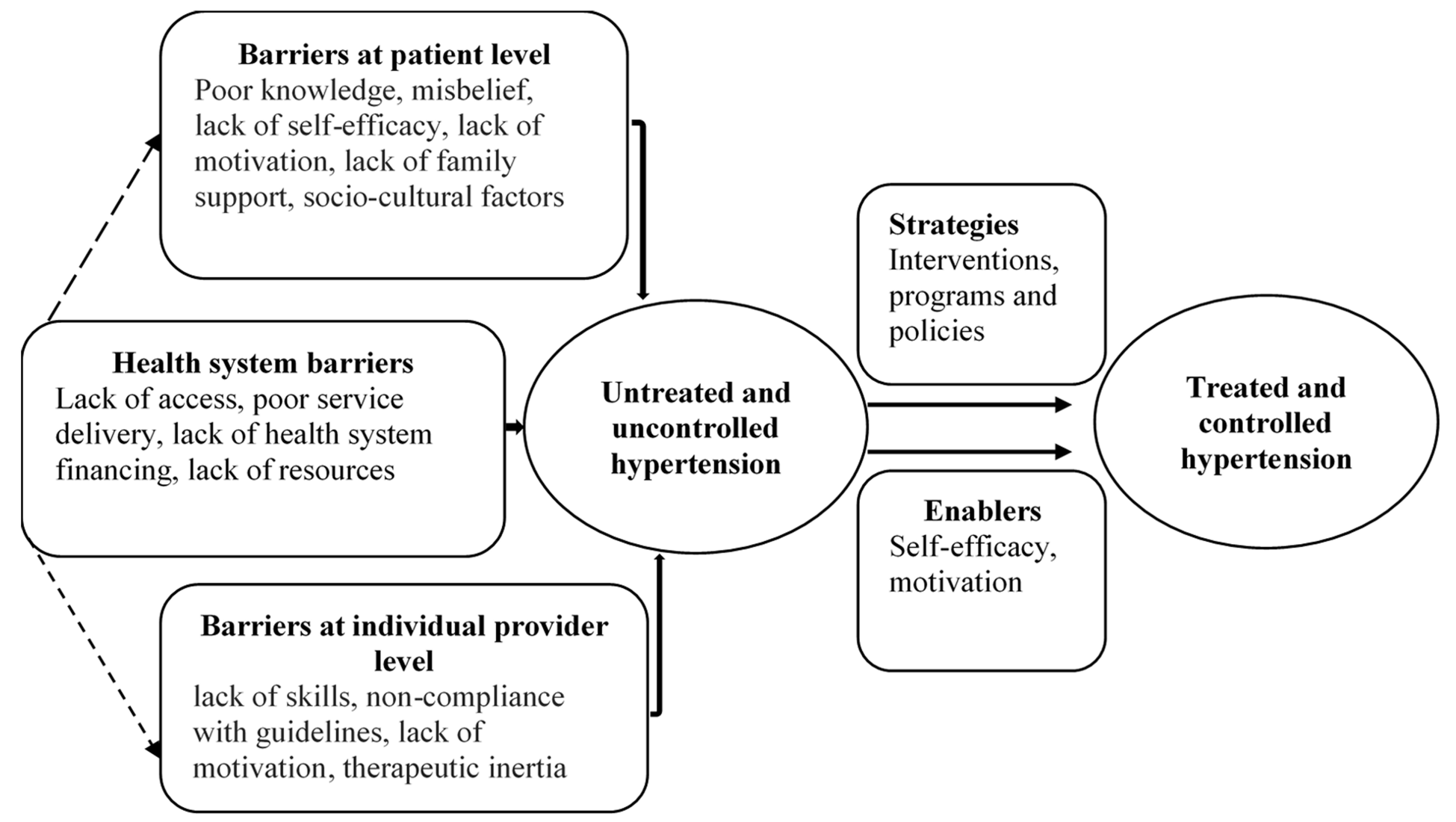

Figure 1

Conceptual framework of barriers, enablers, and strategies for hypertension control 


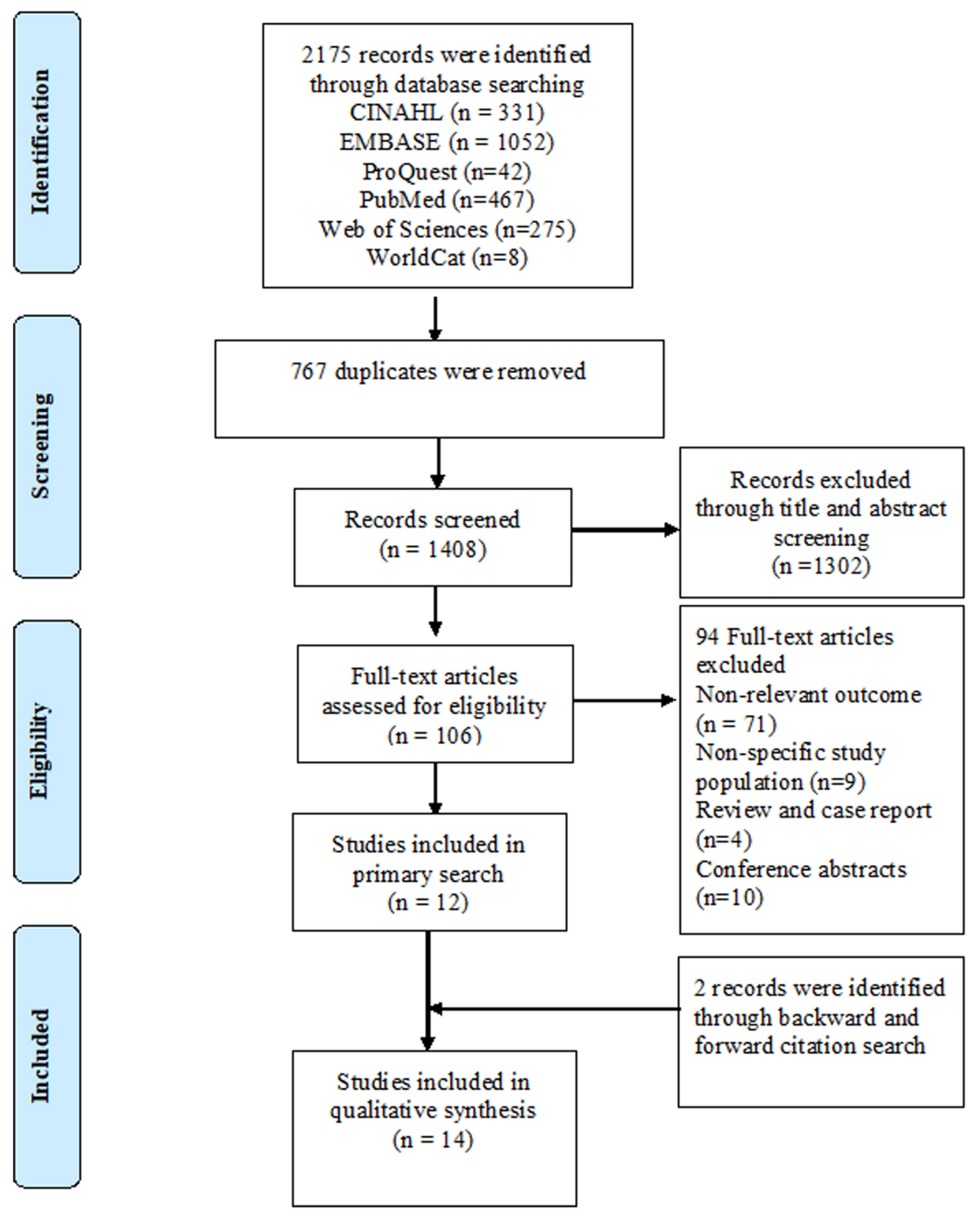

Figure 2

Study selection flow diagram

\section{Supplementary Files}

This is a list of supplementary files associated with this preprint. Click to download.

- Additionalfile2.Qualityassessment.xlsx

- Additionalfile1.Searchstrategy.docx

- PRISMA2009checklist.doc 